Article

\title{
Cadmium Uptake in Native Cacao Trees in Agricultural Lands of Bagua, Peru
}

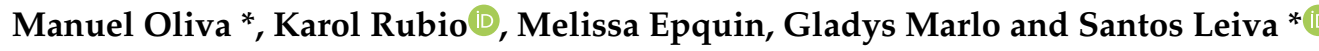 \\ Instituto de Investigación para el Desarrollo Sustentable de Ceja de Selva, Universidad Nacional Toribio \\ Rodríguez de Mendoza de Amazonas, Chachapoyas 01001, Peru; krubio@indes-ces.edu.pe (K.R.); \\ mlerojas34@gmail.com (M.E.); gmarlob0@gmail.com (G.M.) \\ * Correspondence: soliva@indes-ces.edu.pe (M.O.); sleiva@indes-ces.edu.pe (S.L.); \\ Tel.: +51-955-846-507 (M.O.); +51-954-629-617 (S.L.)
}

Received: 21 August 2020; Accepted: 8 October 2020; Published: 11 October 2020

\begin{abstract}
Cadmium (Cd) contamination threatens cocoa farming in the province of Bagua in Amazonas, Peru. This study reports our assessment of $\mathrm{Cd}$ concentrations in cocoa farm soils, and in cocoa roots, leaves, testa, and cotyledon, thus evaluating the magnitude of the problem caused by $\mathrm{Cd}$ exposure. For our analysis, we sampled agricultural soil, cocoa roots, leaves and pods at 29 farms in the province of Bagua. Concentrations of $\mathrm{Cd}$ in each of the samples were measured and correlated with selected variables at each sampling site. Within our collection of samples, Cd levels showed great variability. In soil, $\mathrm{Cd}$ concentrations ranged between 1.02 and $3.54 \mathrm{mg} \mathrm{kg}^{-1}$. Concentrations of this metal within cocoa trees measured from roots, leaves, testa, and cotyledon, $\mathrm{Cd}$ ranged from $0.49 \mathrm{mg} \mathrm{kg}^{-1}$ to $2.53 \mathrm{mg} \mathrm{kg}^{-1}$. The cocoa trees exhibited variable degrees of allocation $\mathrm{Cd}$ from the soil to their tissues and thus considerable variation among themselves. We found that $\mathrm{Cd}$ amounts in roots were up to five times more concentrated than Cd levels in the soils and 2.85 times [Cd] the amounts found in cotyledon. Soil $\mathrm{pH}$ is a key variable enabling the uptake of this metal. Most importantly, our evaluation determined that measurements from the majority of farms exceeded the maximum permissible limits established by Peruvian and European legislation.
\end{abstract}

Keywords: allocation; Amazonas; Cd; cocoa; pollution

\section{Introduction}

Cocoa (Theobroma cacao L.) grown on organic farms represents the principal socio-economic activity in Amazonas state, mainly in the provinces of Bagua and Utcubamba. In 2016, native cocoa widely cultivated in Bagua was awarded the Denomination of Origin "Cacao Amazonas Peru" in recognition of outstanding qualities in flavor and aroma obtained regionally [1].

However, in recent years, $\mathrm{Cd}$ has attracted attention because of its harmful effects on human health and for lowering the quality of foodstuffs. The consumption of products with a high $\mathrm{Cd}$ content leads to serious health problems such as damage to the renal, skeletal, endocrine, reproductive and respiratory systems, while prolonged exposure to $\mathrm{Cd}$ can cause cancer [2-6].

$\mathrm{Cd}$ is found naturally in soils [7]. Weathered rocks, atmospheric deposition, biogenic material and volcanoes are natural sources of $\mathrm{Cd}$ in soils [8,9]. Anthropogenic activity also contributes $\mathrm{Cd}$ to soils, primarily through mining activities, the plastic industry, and rock-based fertilizers $[10,11]$. Moreover, decomposition of leaves and crop residues within cultivated plots has been identified as a major contributor of $\mathrm{Cd}$ found in topsoil [12]. Cd is one of the most mobile elements in soil, with higher bioaccumulation factors than some essential plant nutrients, and mainly accumulates in roots [9]. High concentrations of $\mathrm{Cd}$ have been reported for cocoa beans, and even in final products [13-15]. In Latin America, considerable differences have been reported between the concentrations reported 
both between countries, and within countries $[12,16,17]$. Consequently, multiple studies have sought to identify factors responsible for the high concentration of $\mathrm{Cd}$ in cocoa beans [12,13,17-19]. Evidently, the accumulation of this heavy metal in plants is affected by various factors including soil $\mathrm{pH}$, soil organic matter, soil texture, plant genotypes and the amount of metal available in the environment [7,17-20].

In 2019, Regulation (EU) No. 488/2014, enacted to regulate the Cd content of chocolate and cocoa products, came into force [21], as cocoa had been identified by the European Food Safety Agency (EFSA) as a major source of $\mathrm{Cd}$ in human diet. Limits set by this regulation are therefore of utmost concern to organic cocoa producers in Amazonas, particularly in Bagua province, where there have been reports of shipments rejected because of excessive $\mathrm{Cd}$ content. In response to the maximum permissible limits of Cd for cocoa at $0.6 \mathrm{mg} \mathrm{kg}^{-1}$ set by EC Regulation No. 488/2014 [21], and to address direct and indirect effects of high $\mathrm{Cd}$ concentrations on human health and the local economy, there is an urgent need to understand how $\mathrm{Cd}$ concentrations are distributed in soils where cocoa is grown and the distribution patterns within different parts of the plant.

With these issues in mind, the present study aims to: (1) assess $C d$ concentrations in cocoa farming soils, and cocoa roots, leaves and pods; (2) comprehend the magnitude of the problem of $\mathrm{Cd}$ exposure; and (3) suggest alternative solutions to help farmers cope with the challenges.

\section{Materials and Methods}

\subsection{Site Description}

In Amazonas, mainly native fine flavor cocoa is grown, and its designation of origin guarantees its quality in terms of both flavor and aroma [1]. Our study was conducted on 29 cocoa farms, ranging in age from 5 to 15 years, located in four districts of the province of Bagua in Amazonas (Figure 1). The farms were located at altitudes between 278 and $1176 \mathrm{~m}$ above sea level in a warm tropical climate with an average temperature of $25^{\circ} \mathrm{C}$ and annual rainfall of $500-1500 \mathrm{~mm}$.

On their parcels, cocoa farmers grow only native "criollo" cocoa germoplasm under organic production systems using native tree species as shade.

\subsection{Sampling Methods}

\subsubsection{Soil Sampling}

Soil samples were collected between October and December 2017, at a depth of 0-20 cm, coinciding with a large proportion of active root zone. At each of the farms, a composite sample was taken, along with 20 subsamples of soil, which were subsequently combined and homogenized to obtain a single sample adequately representative of each farm's soil. Samples were also taken from the middle zone of the cocoa tree crown projection. All samples were labelled and sent in plastic bags to the laboratory for analysis.

\subsubsection{Roots, Leaves and Beans Sampling}

Root, leaf and pod samples were collected simultaneously along with the soil samples between October and December 2017. In each plot, 20 cocoa trees were selected adjacent to soil sampling points. At each tree, root samples were taken from the four cardinal points; also, a medium-aged leaf was taken from each of the cardinal points of the tree. Pods were sampled according to availability, at least one mature fruit per tree was collected. After collection, the samples were labelled and transported to the Soil and Water Laboratory of Toribio Rodriguez de Mendoza National University of Amazonas, where they were thoroughly washed with distilled water. Beans were removed from the pods, then mixed to obtain a composite sample for each plot. Roots, leaves and beans were dried at $60^{\circ} \mathrm{C}$, and finally mixed and ground ( 20 mesh) to be stored in labelled plastic bags for further analysis. After drying, the bean samples were separated into two samples representing the testa and the cotyledon before being ground, stored, and analyzed separately. 


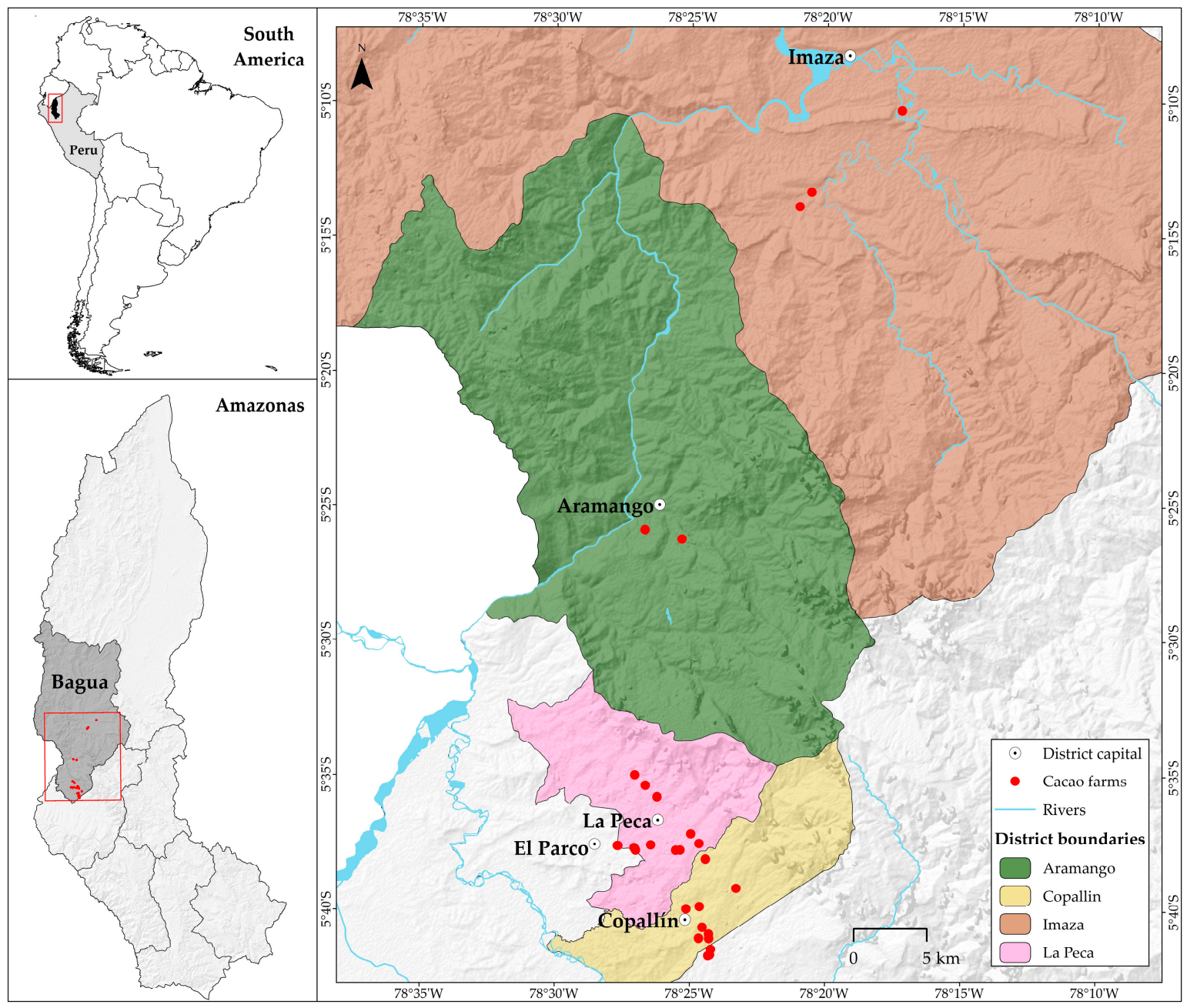

Figure 1. Location of study area and 29 sites within four districts in Bagua, Peru.

\subsection{Lab Analyses}

\subsubsection{Soil Characterization}

Soil samples were analyzed at the Soil and Water Laboratory of Toribio Rodriguez de Mendoza National University of Amazonas to determine pH (1:1), Carbon (\% C), Organic matter (\% O.M.), Nitrogen ( $\% \mathrm{~N}$ ) and particle distribution (\% sand, \% silt, \% clay). Soil $\mathrm{pH}$ was analyzed in suspension with deionized water at 1:1 soil: water ratio. Quantities of organic matter and Carbon were determined using the Walkley Black method [22]. Nitrogen was calculated on the basis of the organic matter content, considering that nitrogen represents $5 \%$ of organic matter content [23]. The particle distribution was determined by the Bouyoucos hydrometer method [24].

\subsubsection{Cd Analysis}

The analyses of $\mathrm{Cd}$ concentration in all samples were done in the Soil Laboratory of the National Agrarian University La Molina. Measurement of Cd in those samples was done by the method 3052 EPA [25].

\subsection{Data Analyses}

The data were analyzed using Minitab v.19.1 statistical software (Minitab LLC, State College, PA, USA). Soil attributes ( $\mathrm{pH}, \mathrm{C}, \mathrm{O} . \mathrm{M}, \mathrm{N}$, particle distribution) were correlated with soil Cd concentrations as well as with individual parts of the cocoa plant (roots, leaves, testa and cotyledon). Jonsson 
transformations (C, O.M, N, Cd in soil), Log10 (\% clay, $\mathrm{Cd}$ in roots, $\mathrm{Cd}$ in leaves and $\mathrm{Cd}$ in cotyledons) and sqrt ( $\mathrm{Cd}$ in testa), were all performed to reach the criterion of normality of the data. Pearson correlation was performed to determine the relationship between soil and plant $\mathrm{Cd}$, and site factors (including altitude, $\mathrm{pH}$, organic matter, nitrogen, and soil particle distribution).

Descriptive statistics such as mean, median, minimum and maximum were also identified. In addition, transfer factor was calculated using the following equation:

$$
\text { FT = Plant Cd/Soil Cd "or" FT = Up plant parts Cd/Root Cd }
$$

where:

- Plant Cd denote the Cd concentrations in roots, leaves, testa and cotyledon

- $\quad$ Soil Cd denote the respective concentrations.

- $\quad$ Up plants Cd denote the Cd concentrations in leaves, testa and cotyledon

\section{Results and Discussion}

\subsection{Sampled Sites and Soil Characteristics}

The sampled plots ranged in elevation from 278 m.a.s.l. in Imaza to 1176 in Copallín. The soils sampled show great variability (Table S1). We observed $\mathrm{pH}$ values ranging from 4.42 to 8.06 . Generally, $\mathrm{pH}$ values varied over a wide range, but in the northern zone of Bagua province (Imaza and Aramango) we found that soils exhibit a low $\mathrm{pH}$. However, in the southern districts of the province (La Peca and Copallín), soils show high $\mathrm{pH}$ values above 6.5.

The organic matter content has varied between $1.03 \%$ and $6.47 \%$. Indeed, it was the lands with more altitude that generally obtained the highest values of organic matter content. The lowest organic matter values are generally related to the alluvial soils of the low terraces formed in this province [26]. The texture of the soils sampled is tends to be Sandy Clay Loam. There are soils with low silt content, and only three samples had over $20 \%$ silt content. The northern zone of this province (Figure 1) showed the highest values of clay content reaching a maximum of $60.36 \%$.

\subsection{Cd Concentrations in Soil-Plant Systems in Cacao Crops in Bagua}

The concentrations of $\mathrm{Cd}$ in soil showed wide variations which vary from 1.02 to $3.54 \mathrm{mg} \mathrm{kg}^{-1}$ (Table S2) and produce a mean of $1.7 \mathrm{mg} \mathrm{kg}^{-1}$. Nevertheless, it was found that only one plot, in Aramango, exceeded $2.7 \mathrm{mg} \mathrm{kg}^{-1}$, usually established as the threshold of $\mathrm{Cd}$ contamination in soils $[9,27]$. These values are similar to those found in agricultural soils of cocoa plantations in Ecuador [17], but are much higher than those reported in Honduras [14], and Bolivia [13]. The best comparison can be made with the values reported by Arevalo-Gardini et al. [28] and Scaccabarozzi et al. [12]. At cocoa plantations in Amazonas, Arevalo-Gardini et al. [28] reported that the agricultural soils of Bagua cocoa plantations contained an average of $0.11 \mathrm{mg} \mathrm{kg}^{-1}$, much lower than the value reported in our study. On the other hand, Scaccabarozzi et al. [12] reported values between 1.6 and $2.3 \mathrm{mg} \mathrm{kg}^{-1}$ of $\mathrm{Cd}$ in agricultural soils of cocoa plantations in Amazonas, averaging samples from Bagua and Condorcanqui. These latter values are closer to those reported in this study. Worldwide, countries have adopted various approaches to determine the level of Cd phytotoxicity in agricultural soils [29-36]. In Peru, the Ministry of Environment set a maximum allowable limit of $1.4 \mathrm{mg} \mathrm{kg}^{-1}$ for Cd levels in agricultural soils. However, in our research $62 \%$ of the sampled plots (Table S2) exceeded this limit [36]. Kabata-Pendias [9] proposed a range between 0.6 and $1.1 \mathrm{mg} \mathrm{kg}^{-1}$, in his study, the Cd concentrations in soils were above this threshold. Therefore, considering the $\mathrm{Cd}$ concentrations reported in this study, it is possible to argue that agricultural soils of cocoa farms in Bagua are contaminated with $\mathrm{Cd}$. No study has been conducted on the origin of $\mathrm{Cd}$ in the soils of this region. Given that the plots sampled have been organically managed, without addition of large amounts of chemical fertilizers, it can be assumed that a major part of the $\mathrm{Cd}$ in the soils of Bagua is of natural origin. $\mathrm{Cd}$ is naturally 
found in soils at different concentrations depending on the region and soil type [7]. Weathering of rocks, atmospheric deposition, biogenic material and volcanoes are natural sources of $\mathrm{Cd}$ in soils $[8,9]$. Moreover, decomposition of leaves and crop residues within the plot is identified as a major source of $\mathrm{Cd}$ found in topsoil [12].

The Cd concentrations in different parts of cocoa trees (Table S2) also varied widely between sampling sites. We found a mean Cd concentration of $1.6 \mathrm{mg} \mathrm{kg}^{-1}, 2.53 \mathrm{mg} \mathrm{kg}^{-1}, 0.49 \mathrm{mg} \mathrm{kg}^{-1}$, and $0.99 \mathrm{mg} \mathrm{kg}^{-1}$ for root, leaf, testa and cotyledon samples respectively. The concentration of $\mathrm{Cd}$ throughout cocoa trees ranged widely. In roots, the minimum $\mathrm{Cd}$ amounts are $0.03 \mathrm{mg} \mathrm{kg}^{-1}$ and the maximum reach $8.95 \mathrm{mg} \mathrm{kg}^{-1}$. Leaves also accumulated high concentrations of $\mathrm{Cd}$, exhibiting the minimum amounts of $0.4 \mathrm{mg} \mathrm{kg}^{-1}$ and reaching a maximum of $8.08 \mathrm{mg} \mathrm{kg}^{-1}$. The Cd concentrations in leaves tended to be higher than root $\mathrm{Cd}$ concentrations. Former studies have reported this tendency for cocoa to store high concentrations of $\mathrm{Cd}$ in leaves $[13,14,17,19,37]$.

Testa and cotyledon shows lower $\mathrm{Cd}$ concentrations with minimum $\mathrm{Cd}$ amounts of 0.03 and $0.14 \mathrm{mg} \mathrm{kg}^{-1}$, and maximum Cd concentrations of 3.03 and $5.12 \mathrm{mg} \mathrm{kg}^{-1}$ respectively (Figure 2A,B). Variable $\mathrm{Cd}$ concentrations in cocoa tissue should be, in combination with the chemical parameters of the soil, due to the differential response of plants to heavy metal exposure $[9,19]$.
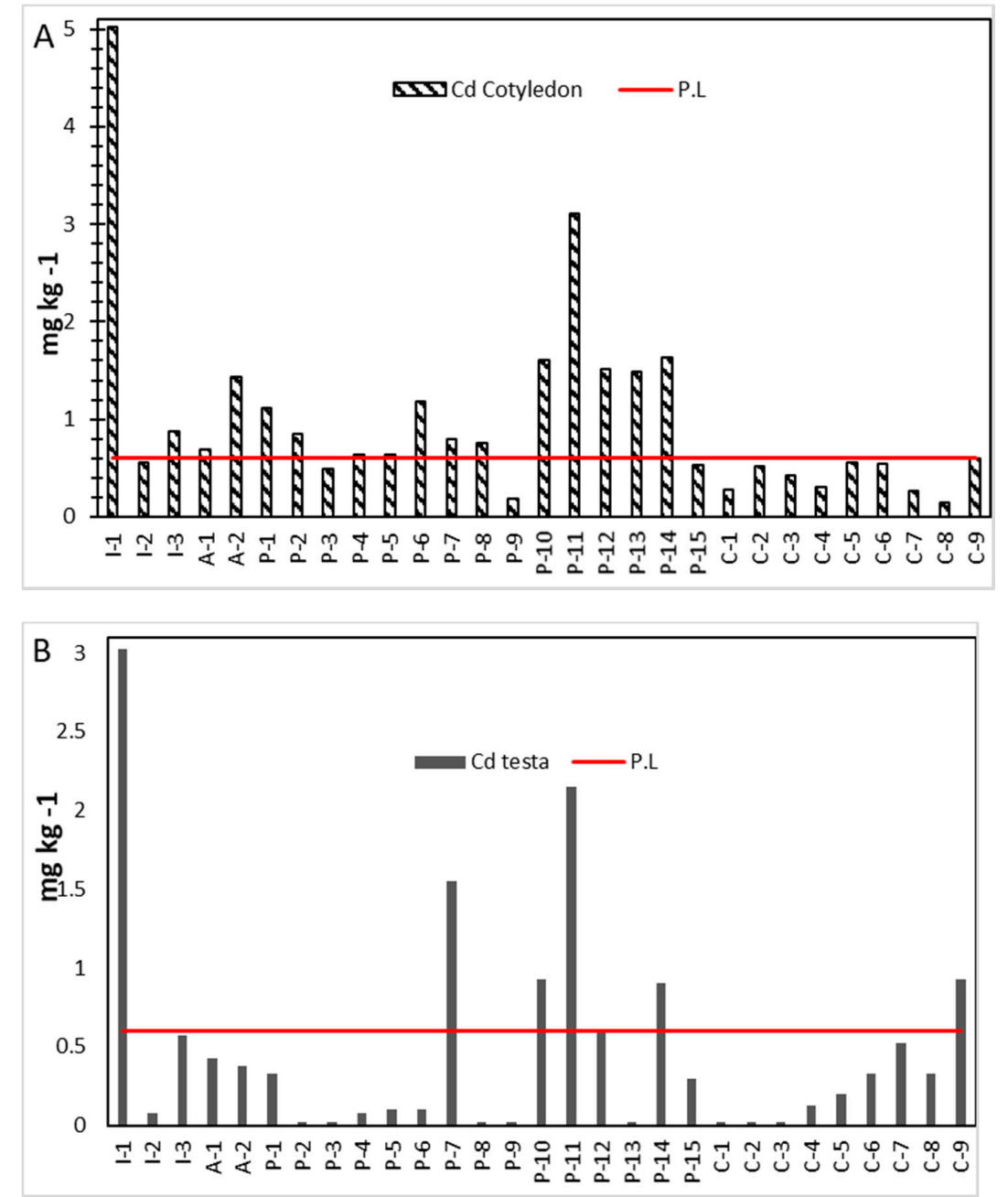

Figure 2. Cd contents in cotyledon (A) and testa (B). Red line indicates Cd threshold in cacao cotyledon set at $0.6 \mathrm{mg} \mathrm{kg}^{-1}$.

As we mentioned above, the European Food Safety Agency (EFSA) has identified cocoa as a major source of $\mathrm{Cd}$ for human consumption and has consequently set maximum permitted limits for $\mathrm{Cd}$ in 
cocoa products which came into force in 2019 [21]. This regulation sets a threshold of $0.1 \mathrm{mg} \mathrm{kg}^{-1}$ of $\mathrm{Cd}$ for milk chocolate containing less than $30 \%$ dry cocoa solids, and $0.8 \mathrm{mg} \mathrm{kg}^{-1}$ for dark chocolates containing $50 \%$ dry cocoa solids. Cocoa powder sold as a final product to the consumer should have maximum levels below $0.6 \mathrm{mg} \mathrm{kg}^{-1}$. Our determination that, in $59 \%$ of the plots evaluated, $\mathrm{Cd}$ concentrations exceeded the permissible limit of $0.6 \mathrm{mg} \mathrm{kg}^{-1}$ (Figure 2A) exposes the problem faced by cocoa farmers in Bagua province, subject to the legally established restrictions.

\subsection{Uptake and Allocation of Cd to Different Organs of Cocoa Trees}

Table S2 shows Cd transfer factors (TF) between the soil and the cocoa tree parts analyzed obtaining a wide ranged data. This TF shows how the $\mathrm{Cd}$ is allocated from soil to cacao tree. Cocoa trees in Bagua province accumulate up to five times the concentration of $\mathrm{Cd}$ found in the soil within their roots (Table S2). However, cotyledon accumulates up to 2.85 times the concentration of Cd found in soil. Some plant species have the capacity to tolerate high concentrations of heavy metals within soils, either by sequestering these metals in their roots, or by removing them through their stomas [38,39]. Two factors can be identified to account for higher $\mathrm{Cd}$ concentrations found in cocoa plants than within the soil: the $\mathrm{Cd}$ bioavailability, and the cocoa trees' propensity to accumulate $\mathrm{Cd}$. Chemical Cd speciation provides information on Cd bioavailability [40]. Although our study did not focus on this, it deserves mention, because many studies have suggested that plant-available $\mathrm{Cd}$ is in one of three soluble forms, either water-soluble, exchangeable, or acid-soluble [41-43]. Consequently, plant $\mathrm{Cd}$ cannot be interpreted how total soil $\mathrm{Cd}$, since low soil $\mathrm{Cd}$ concentrations may lead to high plant $\mathrm{Cd}$ concentrations, and vice-versa, due to differences in the form of plant-available $\mathrm{Cd}$ [44]. In general, the cacao plant is prone to accumulation of $\mathrm{Cd}$; recently, $12.56 \mathrm{mg} \mathrm{kg}^{-1}$ of Cd concentration was reported for Peruvian cacao [45], indicating that cacao is a $\mathrm{Cd}$ accumulating plant species [14]. The allocation of Cd into the plant is strongly related with soil conditions. McLaughlin [46] reported that lime application significantly reduces the absorption rates of $\mathrm{Cd}$ by cacao, probably due to decline in soil acidity.

Regarding Cd allocation, $\mathrm{Cd}$ concentrations in leaves were reported to be 123 times higher than the concentrations of $\mathrm{Cd}$ contained in roots. Likewise, the concentration of $\mathrm{Cd}$ in cotyledon was up to 28.6 times higher than in cocoa roots (Table S2). However, even though the majority of samples presented high transfer factors, there were also some samples where TF showed minimal amounts of Cd uptake by roots from soil and into other parts of the plant (Table S2). A large number of species have been reported to have different patterns of heavy metal accumulation from one genotype to another [47-51]. For the cocoa genotype, not many studies have reported data on heavy metal accumulation. Nevertheless, Arevalo-Gardini et al. [18] reported different levels of uptake and translocation in various cocoa cultivars. Additionally, Lewis et al. [19] reported variations in the accumulation of Cd in 100 cocoa accessions from the International Cocoa Genebank, Trinidad (ICGT). Recently, a gene encoding Cd binding protein has been reported [52], and these proteins could be the reason for high soil-to-plant and root-to-vegetative transfer factors [53]. By and large, in Bagua a great diversity of cocoa trees varieties was identified in the sampled farms, which may explain the variable patterns of Cd uptake, distribution, and accumulation within a cocoa crop.

\subsection{Correlation of Soil and Plant $C d$ with Site Factors}

Values for Pearson's correlations between Cd content in soil and cocoa plants and the variables evaluated are shown in Table 1. Taking into account soil $\mathrm{pH}$ values, we found a positive correlation with soil $\mathrm{Cd}(p<0.05)$, which is supported by several other studies. Indeed, those studies reported a strong correlation between soil Cd and soil $\mathrm{pH}[17,28]$. Regarding $\mathrm{Cd}$ levels found in cocoa root tissues, there is a surprisingly weak correlation with soil $\mathrm{pH}(p<0.05)$, but a strong correlation with altitude $(p<0.01)$ is evident. Furthermore, $C d$ concentrations in leaves shows a significant but negative correlation with percentage of sand in soil $(p<0.05)$. The concentration of $\mathrm{Cd}$ in cotyledons displays a significant negative correlation with the $\mathrm{pH}$ and sand content of the soils under study. 
Table 1. Correlation coefficients ( $\mathrm{r}$ ) between Cd content in soil and plant samples and top soil properties, including farm altitudes. ${ }^{*} p \leq 0.05 ;{ }^{* *} p \leq 0.01$ ).

\begin{tabular}{|c|c|c|c|c|c|c|c|c|c|c|c|c|}
\hline & Altitude & Soil pH & $\begin{array}{l}\text { Carbon } \\
\text { Content }\end{array}$ & $\begin{array}{c}\text { Soil Organic } \\
\text { Matter }\end{array}$ & $\begin{array}{c}\text { Soil } \\
\text { Nitrogen }\end{array}$ & $\begin{array}{c}\text { Sand } \\
\text { Content }\end{array}$ & $\begin{array}{c}\text { Silt } \\
\text { Content }\end{array}$ & $\begin{array}{c}\text { Clay } \\
\text { Content }\end{array}$ & $\begin{array}{l}\text { Soil Cd } \\
\text { Content }\end{array}$ & $\begin{array}{l}\text { Root Cd } \\
\text { Content }\end{array}$ & $\begin{array}{l}\text { Leaf Cd } \\
\text { Content }\end{array}$ & $\begin{array}{l}\text { Cotyledon } \\
\text { Cd Content }\end{array}$ \\
\hline Cd Soil & & 0.291 * & 0.198 & 0.198 & 0.198 & 0.034 & 0.133 & -0.012 & & & & \\
\hline Cd root & $0.349 * *$ & -0.314 * & 0.057 & 0.057 & 0.057 & -0.259 & 0.184 & 0.131 & $-0.432 * *$ & & & \\
\hline Cd Leaf & 0.136 & -0.258 & 0.206 & 0.206 & 0.206 & -0.293 * & 0.236 & 0.106 & -0.187 & $0.415^{* *}$ & & \\
\hline Cd Testa & 0.139 & -0.249 & 0.138 & 0.138 & 0.138 & -0.225 & 0.15 & 0.077 & 0.121 & $0.399 * *$ & $0.526^{* *}$ & \\
\hline Cd Cotyledon & -0.028 & -0.284 * & -0.136 & -0.136 & -0.136 & -0.291 * & 0.248 & 0.124 & -0.258 & 0.288 * & $0.684^{* *}$ & $0.548 * *$ \\
\hline
\end{tabular}


Other studies have reported correlations between $\mathrm{Cd}$ in soil and Cd in plants $[17,54]$. In this study, no significant correlations were found between $\mathrm{Cd}$ in soil and $\mathrm{Cd}$ in the cacao plants; these controversial results could be because we evaluated total $\mathrm{Cd}$, while those authors evaluated available $\mathrm{Cd}$.

The $\mathrm{pH}$ level is considered to be the key variable for both $\mathrm{Cd}$ availability in soils and for $\mathrm{Cd}$ uptake by cocoa cotyledon. In this study, higher concentrations of $\mathrm{Cd}$ were reported in the low-altitude zones, where the soils are alluvial, and soil $\mathrm{pH}$ and organic matter contents were relatively lower than at higher altitudes. Soil organic matter and soil $\mathrm{pH}$ control $\mathrm{Cd}$ transport, and they are also associated with negative correlations between $\mathrm{pH}$ and soluble $\mathrm{Cd}$ in soils [55-57]. This may explain why in our study low soil $\mathrm{pH}$ correlates with high $\mathrm{Cd}$ concentrations in cocoa roots. Several other variables have an impact on the behavior of $\mathrm{Cd}$ in soils including CEC, clay content and metal concentration [58].

We observe a negative correlation $(p<0.05)$ between sand content and the concentration of $\mathrm{Cd}$ in cocoa leaves and cotyledons, and thus it can be inferred that clay or loamy soils are favorable for $\mathrm{Cd}$ uptake, as reported by Huamani-Yupanqui et al. [20].

Regarding Cd content in the different cocoa parts, we noted that the Cd content not only in roots showed a highly significant correlation $(p<0.01) \mathrm{Cd}$ in leaves, and beans of the cocoa (Table 1$)$. Other studies have also reported the correlation between $\mathrm{Cd}$ concentrations found in parts of cocoa plant $[14,17]$.

\section{Conclusions}

Concentrations of $\mathrm{Cd}$ found in cocoa cotyledon, expressed in most of our samples, exceeded the maximum limits set in the EC Regulation No. 488/2014. This is therefore a major problem for cocoa farmers in Bagua Province. The high levels of Cd transfer from the soil to the roots of the cocoa, and from roots to the rest of the plant are of particular concern. Soil pH is one of the most important characteristics governing $\mathrm{Cd}$ uptake in cacao plantations.

As a recommendation for mitigating the problem of soil contamination, cocoa trees should be identified that possess low transfer factors, i.e., that do not capture $\mathrm{Cd}$ from the soil or otherwise sequester the metal in their roots or leaves without transferring it to the cotyledons. It is urgent that efforts are initiated to eliminate $\mathrm{Cd}$ from the native cocoa agroecosystem of Bagua. As alternatives, we recommend soil amendments, bioremediation with microorganisms, and bioextraction with plants capable of absorbing Cd.

Supplementary Materials: The following are available online at http://www.mdpi.com/2073-4395/10/10/1551/s1. Table S1: Altitude and top soil parameters in all farms analyzed. (Av \pm S.E $=$ Average \pm standard errors). Table S2: Soil and plant (Root, Leaf, Testa, and Cotyledon) Cd concentrations found in all farms analyzed, include transfer factors.

Author Contributions: Conceptualization, M.O. and S.L.; methodology, M.O., S.L. and K.R.; formal analysis, K.R.; investigation, M.E., S.L., and G.M.; writing-original draft preparation, K.R., M.E.; writing-review and editing, M.O., K.R., and S.L.; funding acquisition, M.O., and S.L. All authors have read and agreed to the published version of the manuscript.

Funding: This research was funded by National Fund for Scientific, Technological an Innovation Development-FONDECYT, contract number 026-2016-fondecyt (CINCACAO project), and The APC was funded by SNIP project No. 352641. "Creation and Implementation of the Cocoa Research and Technological Innovation Center at The Toribio Rodríguez of Mendoza National University, Amazon Region" - CEINCACAO.

Acknowledgments: Sincere acknowledgement to Warren B. Church of Columbus State University, Georgia, USA who assisted with the writing/translation of the manuscript.

Conflicts of Interest: The authors declare no conflict of interest.

\section{References}

1. INDECOPI. Cacao Amazonas Peru: Resolución Nº14866-2016/DSD-INDECOPI; INDECOPI: Lima, Perú, 2016.

2. World Health Organization. Exposure to Cadmium: A Major Public Health Concern; World Health Organization: Geneva, Switzerland, 2010; pp. 3-6. 
3. Järup, L.; Åkesson, A. Current status of cadmium as an environmental health problem. Toxicol. Appl. Pharmacol. 2009, 238, 201-208. [CrossRef] [PubMed]

4. Nawrot, T.S.; Staessen, J.A.; Roels, H.A.; Munters, E.; Cuypers, A.; Richart, T.; Ruttens, A.; Smeets, K.; Clijsters, H.; Vangronsveld, J. Cadmium exposure in the population: From health risks to strategies of prevention. BioMetals 2010, 23, 769-782. [CrossRef] [PubMed]

5. Åkesson, A.; Barregard, L.; Bergdahl, I.A.; Nordberg, G.F.; Nordberg, M.; Skerfving, S. Commentary Non-renal effects and the risk assessment of environmental. Environ. Health Perspect. 2014, 122, 431-438. [CrossRef] [PubMed]

6. Kazantzis, G. Cadmium, Osteoporosis and calcium metabolism. BioMetals 2004, 17, 493-498. [CrossRef] [PubMed]

7. Alloway, B.J. Heavy Metals in Soils; Blackie Academic \& Professional: London, UK, 2013.

8. Khan, M.A.; Khan, S.; Khan, A.; Alam, M. Soil contamination with cadmium, consequences and remediation using organic amendments. Sci. Total Environ. 2017, 601-602, 1591-1605. [CrossRef]

9. Kabata-Pendias, A. Trace Elements in Soils and Plants, 4th ed.; Taylor and Francis Group: London, UK, 2011.

10. He, Q.B.; Singh, B.R. Crop uptake of cadmium from phosphorus fertilizers: I. yield and cadmium content. Water Air Soil Pollut. 1994, 74, 251-265. [CrossRef]

11. Jiao, W.; Chen, W.; Chang, A.C.; Page, A.L. Environmental risks of trace elements associated with long-term phosphate fertilizers applications: A review. Environ. Pollut. 2012, 168, 44-53. [CrossRef]

12. Scaccabarozzi, D.; Castillo, L.; Aromatisi, A.; Milne, L.; Búllon Castillo, A.; Muñoz-Rojas, M. Soil, site, and management factors affecting cadmium concentrations in cacao-growing soils. Agronomy 2020, $10,806$. [CrossRef]

13. Gramlich, A.; Tandy, S.; Andres, C.; Chincheros Paniagua, J.; Armengot, L.; Schneider, M.; Schulin, R. Cadmium uptake by cocoa trees in agroforestry and monoculture systems under conventional and organic management. Sci. Total Environ. 2017, 580, 677-686. [CrossRef]

14. Gramlich, A.; Tandy, S.; Gauggel, C.; López, M.; Perla, D.; Gonzalez, V.; Schulin, R. Soil cadmium uptake by cocoa in honduras. Sci. Total Environ. 2018, 612, 370-378. [CrossRef]

15. Manton, W.I. Nonnutritive constituents in chocolate and cocoa. In Chocolate in Health and Nutrition; Humana Press: Totowa, NJ, USA, 2013; pp. 73-87. [CrossRef]

16. Mounicou, S.; Szpunar, J.; Andrey, D.; Blake, C.; Lobinski, R. Concentrations and bioavailability of cadmium and lead in cocoa powder and related products. Food Addit. Contam. 2003, 20, 343-352. [CrossRef] [PubMed]

17. Chavez, E.; He, Z.L.; Stoffella, P.J.; Mylavarapu, R.S.; Li, Y.C.; Moyano, B.; Baligar, V.C. Concentration of cadmium in cacao beans and its relationship with soil cadmium in southern ecuador. Sci. Total Environ. 2015, 533, 205-214. [CrossRef] [PubMed]

18. Arévalo-Gardini, E.; Arévalo-Hernández, C.O.; Baligar, V.C.; He, Z.L. Heavy metal accumulation in leaves and beans of cacao (theobroma cacao L.) in major cacao growing regions in peru. Sci. Total Environ. 2017, 605-606, 792-800. [CrossRef] [PubMed]

19. Lewis, C.; Lennon, A.M.; Eudoxie, G.; Umaharan, P. Genetic Variation in Bioaccumulation and Partitioning of Cadmium in Theobroma cacao L. Sci. Total Environ. 2018, 640-641, 696-703. [CrossRef] [PubMed]

20. Huamaní-Yupanqui, H.A.; Huauya-Rojas, M.Á.; Mansilla-Minaya, L.G.; Florida-Rofner, N.; Neira-Trujillo, G.M. Presencia de metales pesados en cultivo de cacao (Theobroma cacao L.) orgánico. Acta Agron. 2012, 61, 339-344.

21. The European Comission. Commission regulation (EU) No 488/2014 of 12 May 2014 amending regulation (EC) No 1881/2006 as regards maximum levels of cadmium in foodstuffs. Off. J. Eur. Union 2014, 488, 75-79.

22. Walkley, A.; Black, I.A. An examination of the degtjareff method for determining soil organic matter, and proposed modification on the chromic acid titration method. Soil Sci. 1934, 37, 29-38. [CrossRef]

23. Jackson, M.L. Soil Chemical Analysis, 2nd ed.; Parallel Press: Madison, WI, USA, 1985.

24. Bouyoucos, G.J. Hydrometer method improved for making particle size analyses of soils. Agron. J. 1962, 54, 464-465. [CrossRef]

25. US EPA. SW-846 Test Method 3052: Microwave Assisted Acid Digestion of Siliceous and Organically Based Matrices; US EPA: Washington, DC, USA, 1996. Available online: https://www.epa.gov/sites/production/files/2015-12/ documents/3052.pdf (accessed on 12 June 2020).

26. Rodríguez, F.; Limachi, L.; Reátegui, F.; Escobedo, R.; Ramírez, J.; Encarnación, F.; Maco, J.; Guzmán, W.; Castro, W.; Lizardo, M.; et al. Zonificación Ecológica y Económica de Amazonas; IIAP-Gobierno Regional Amazonas, Ed.; IIAP: Amazonas, 2010. 
27. McLaughlin, M.J.; Maier, N.A.; Rayment, G.E.; Sparrow, L.A.; Berg, G.; McKay, A.; Milham, P.; Merry, R.H.; Smart, M.K. Cadmium in Australian potato tubers and soils. J. Environ. Qual. 1997, 26, 1644-1649. [CrossRef]

28. Arévalo-Gardini, E.; Obando-Cerpa, M.E.; Zúñiga-Cernades, L.B.; Arévalo-Hernández, C.O.; Baligar, V.; He, Z. Metales pesados en suelos de plantaciones de cacao (Theobroma cacao L.) en tres regiones del perù. Ecol. Apl. 2016, 15, 81. [CrossRef]

29. The Council of the European Communities. Council Directive 86/278/EEC, on the protection of the environment, and in particular of the soil when, sewage sludge is used in agriculture. Off. J. Eur. Comm. 1986, 181, 6-12.

30. McGrath, S.P.; Chang, A.C.; Page, A.L.; Witter, E. Land application of sewage sludge: Scientific perspectives of heavy metal loading limits in Europe and the United States. Environ. Rev. 1994, 2, 108-118. [CrossRef]

31. United States Environmental Protection Agency. Supplemental Guidance for Developing Soil Screening Levels for Superfund Sites; US EPA: Washington, DC, USA, 2002.

32. D.Lgs 152/2006. Decreto legislativo 3 April 2006, n. 152. norme in materia ambientale. In Gazzetta Ufficiale n. 88 del 14-4-2006, Suppl. Ordinario n. 96; 2006. Available online: https://www.isprambiente.gov.it/it/ garante_aia_ilva/normativa/normativa-ambientale/Dlgs_152_06_TestoUnicoAmbientale.pdf (accessed on 12 June 2020).

33. Carlon, C.; D'Alessandro, M.; Swartjes, F. Derivation methods of soil screening values in Europe. In A Review and Evaluation of National Procedures towards Harmonization; Carlon, C., Ed.; European Commission, Joint Research Centre: Ispra, Varese, Italy, 2007.

34. Finnish Ministry of the Environment. Government Decree on the Assessment of Soil Contamination and Remediation Needs, 214/2007; Finnish Government: Helsinki, Finland, 2007.

35. Chinese Ministry of Environmental Protection \& Ministry of Land and Resources. Report on the National Soil Contamination Survey; 2014. Available online: www.zhb.gov.cn/gkml/hbb/qt/201404/t20140417_270670.htm (accessed on 25 May 2020). (In Chinese)

36. Ministerio del Ambiente Perú. Decreto supremo N 011-2017-MINAM: Aprueban Estándares de Calidad Ambiental (ECA) para Suelo. El Peruano 2017, 192, 12-15.

37. Ramtahal, G.; Chang Yen, I.; Ahmad, N.; Bekele, I.; Bekele, F.; Maharaj, K.; Wilson, L.; Harrynanan, L. Prediction of Soil cadmium bioavailability to cacao (Theobroma cacao L.) using single-step extraction procedures. Commun. Soil Sci. Plant Anal. 2015, 46, 2585-2594. [CrossRef]

38. Peer, W.A.; Baxter, I.R.; Richards, E.L.; Freeman, J.L.; Murphy, A.S. Phytoremediation and Hyperaccumulator Plants. In Molecular Biology of Metal Homeostasis and Detoxification From Microbes to Man; Topics in Current Genetics; Tamás, M.J., Martinoia, E., Eds.; Springer: Berlin/Heidelberg, Germany, 2005. [CrossRef]

39. He, S.; He, Z.; Yang, X.; Stoffella, P.J.; Baligar, V.C. Soil biogeochemistry, plant physiology, and phytoremediation of cadmium- contaminated soils. In Advances in Agronomy; Elsevier Ltd.: Amsterdam, The Netherlands, 2015; Volume 134, pp. 135-225. [CrossRef]

40. Krishnamurti, G.S.; Megharaj, M.; Naidu, R. Bioavailability of cadmium-organic complexes to soil alga-an exception to the free ion model. J. Agric. Food Chem. 2004, 52, 3894-3899. [CrossRef]

41. Anju, M.; Banerjee, D.K. Associations of cadmium, zinc, and lead in soils from a lead and zinc mining area as studied by single and sequential extractions. Environ. Monit. Assess. 2011, 176, 67-85. [CrossRef]

42. Kosolsaksakul, P.; Farmer, J.G.; Oliver, I.W.; Graham, M.C. Geochemical associations and availability of cadmium (Cd) in a paddy field system, Northwestern Thailand. Environ. Pollut. 2014, 187, 153-161. [CrossRef]

43. Sungur, A.; Soylak, M.; Ozcan, H. Investigation of heavy metal mobility and availability by the bcr sequential extraction procedure: Relationship between soil properties and heavy metals availability. Chem. Speciat. Bioavailab. 2014, 26, 219-230. [CrossRef]

44. Maddela, N.R.; Kakarla, D.; García, L.C.; Chakraborty, S.; Venkateswarlu, K.; Megharaj, M. Cocoa-laden cadmium threatens human health and cacao economy: A critical view. Sci. Total Environ. 2020, 720, 137645. [CrossRef]

45. Zug, K.L.M.; Huamaní Yupanqui, H.A.; Meyberg, F.; Cierjacks, J.S.; Cierjacks, A. Cadmium accumulation in peruvian cacao (theobroma cacao L.) and opportunities for mitigation. Water Air Soil Pollut. 2019, 230, 72. [CrossRef] 
46. McLaughlin, M. Heavy metals in agriculture with a focus on Cd. In Ecuador Soil Congress; CSIRO Land and Water Fertilizer Technology Research Centre, Waite Research Institute, University of Adelaide: Adelaide, Australia, 2016.

47. Zacchini, M.; Pietrini, F.; Scarascia Mugnozza, G.; Iori, V.; Pietrosanti, L.; Massacci, A. Metal tolerance, accumulation and translocation in poplar and willow clones treated with cadmium in hydroponics. Water Air Soil Pollut. 2009, 197, 23-34. [CrossRef]

48. Dai, H.; Yang, Z. Variation in Cd accumulation among radish cultivars and identification of low-Cd cultivars. Environ. Sci. Pollut. Res. 2017, 24, 15116-15124. [CrossRef] [PubMed]

49. Zeng, F.; Mao, Y.; Cheng, W.; Wu, F.; Zhang, G. Genotypic and environmental variation in chromium, cadmium and lead concentrations in rice. Environ. Pollut. 2008, 153, 309-314. [CrossRef] [PubMed]

50. Liu, C.-S.; Sun, B.-Y.; Kan, S.-H.; Zhang, Y.-Z.; Deng, S.-H.; Yang, G. Copper toxicity and accumulation in potted seedlings of three apple rootstock: Implications for safe fruit production on copper-polluted soils. J. Plant Nutr. 2011, 34, 1268-1277. [CrossRef]

51. Francini, A.; Sebastiani, L. Copper Effects on Prunus persica in Two Different Grafting Combinations (P. persica $\times$ P. amygdalus and P. cerasifera). J. Plant Nutr. 2010, 33, 1338-1352. [CrossRef]

52. Ullah, I.; Wang, Y.; Eide, D.J.; Dunwell, J.M. Evolution, and functional analysis of natural resistance-associated macrophage proteins (NRAMPs) from theobroma cacao and their role in cadmium accumulation. Sci. Rep. 2018, 8, 14412. [CrossRef]

53. Satarug, S.; Garrett, S.H.; Sens, M.A.; Sens, D.A. Cadmium, environmental exposure, and health outcomes. Cien. Saude Colet. 2011, 16, 2587-2602. [CrossRef]

54. Ramtahal, G.; Yen, I.C.; Bekele, I.; Bekele, F.; Wilson, L.; Maharaj, K.; Harrynanan, L. Relationships between cadmium in tissues of cacao trees and soils in plantations of trinidad and tobago. Food Nutr. Sci. 2016, 7, 37-43. [CrossRef]

55. Adams, M.L.; Zhao, F.J.; Mcgrath, S.P.; Nicholson, F.A.; Chambers, B.J. Predicting cadmium concentrations in wheat and barley grain using soil properties. J. Environ. Qual. 2004, 33, 532-541. [CrossRef]

56. Kirkham, M.B. Cadmium in plants on polluted soils: Effects of soil factors, hyperaccumulation, and amendments. Geoderma 2006, 137, 19-32. [CrossRef]

57. Degryse, F.; Broos, K.; Smolders, E.; Merckx, R. Soil solution concentration of Cd and Zn canbe predicted with a $\mathrm{CaCl} 2$ soil extract. Eur. J. Soil Sci. 2003, 54, 149-158. [CrossRef]

58. Wang, X.; Shan, X.; Zhang, S.; Wen, B. A model for evaluation of the phytoavailability of trace elements to vegetables under the field conditions. Chemosphere 2004, 55, 811-822. [CrossRef] [PubMed] 